\title{
Multicultural Values: An Analysis of the Indonesian Literacy Disregard
}

\author{
Slamet \\ History Education study program Faculty of Teacher Training and Education IVET University of \\ Indonesia \\ slametikipvetsmg@yahoo.com
}

\begin{abstract}
The background of this study is a pluralistic and multicultural Indonesian nation-state from culture, religion, ethnicity, ethnicity, social, and territorial heritage as a prehistoric / pre-literacy era that often arises due to conflict due to friction from a variety of diversity, so there needs to be a solution as a solution to the application of multicultural values to an educational institution. The purpose of this study is to describe: 1) the social system; 2) belief system; 3) science and technology; 4) artistry; 5) agriculture; and 6) shipping. This type of research is designed using a descriptive approach, while the form of research uses a content analysis model, then in practice, it refers to the content analysis procedure. The results of the study concluded that one of the major problems of this nation is the awareness of the identity of a nation-state. This is due to 2 (two) waves of social change, namely globalization and democracy. At the global level, in addition to the existence of world powers such as in politics and trade, there is also a power that wants people to have an awareness of their identities, so we need a unity of the nation that is awareness in the container and frame of the Unitary State of the Republic of Indonesia.
\end{abstract}

Keywords: Multicultural Values; Prehistoric

\begin{abstract}
Abstrak. Latar belakang kajian ini adalah negara-bangsa Indonesia yang plural dan multikultur dari budaya, agama, etnis, suku, sosial, dan kewilayahan sebagai warisan jaman prasejarah/praaksara yang sering muncul adanya konflik disebabkan oleh adanya gesekan dari berbagai keragaman, sehingga perlu adanya solusi sebagai jalan pemecahan dengan penerapan nilai-nilai multikultur pada sebuah institusi pendidikan. Tujuan kajian ini adalah mendeskripsikan: 1) sistem sosial kemasyarakatan; 2) sistem kepercayaan; 3) ilmu pengetahuan dan teknologi; 4) kesenian; 5) pertanian; dan 6) pelayaran. Jenis penelitian didesain dengan menggunakan pendekatan deskriptif, sedangkan bentuk penelitian digunakan model analisis isi (content analysis), maka dalam pelaksanaannya mengacu pada prosedur analisis isi. Hasil penelitian diperoleh simpulan bahwa salah satu masalah besar bangsa ini adalah kesadaran identitas suatu negara-bangsa. Hal ini disebabkan adanya 2 (dua) gelombang perubahan sosial, yaitu globalisasi dan demokrasi. Pada tingkat global selain adanya kekuatan-kekuatan dunia seperti dalam bidang politik dan perdagangan, muncul pula kekuatan yang menginginkan orang memiliki kesadaran akan identitasnya, maka diperlukan sebuah persatuan bangsa yaitu kesadaran dalam wadah dan bingkai NKRI.
\end{abstract}

Kata Kunci: Nilai-Nilai Multikulrutal; Prasejarah 


\section{INTRODUCTION}

The inculcation of multicultural values in education is believed to be a real solution to the conflicts and disharmony that occur in society, especially those that often occur in Indonesian society which in reality as a plural nation-state. In other words, multicultural education can be an alternative means of resolving social and cultural conflicts (Parekh, 2012). The diverse cultural spectrum of Indonesian society is a challenge for education to process the difference into an asset, not a source of division. At present multicultural education has 2 (two) major responsibilities, namely: 1) preparing the nation to face the flow of outside culture in the era of globalization; and 2) 'uniting' the nation itself which consists of various cultures (Naim and Sauqi, 2011).

Nationalism and ideology education has been widely provided ranging from basic education to tertiary institutions, but multicultural education has not been provided in the correct proportions. Therefore, schools and colleges as educational institutions can develop multicultural education with models according to the principle of educational autonomy or their respective schools. In my opinion, multicultural education should be emphasized more on the subjects of nationality and morals, as well as subjects: History, Civics, Religion, and BK (Slamet, 2017).

Previous learning models related to nationality do exist, but they are still in adequate as a means of education to appreciate differences: ethnicity, culture, ethnicity, religion, language, territoriality, and other diversity. This condition can be seen from the emergence of conflicts that often occur in the reality of national and state life today, these conditions indicate that understanding of tolerance is still low and very lacking. Supriyoko Said (2011); that until now the number of students and students who understand something that exists behind the nation's culture is still lacking, even the public knows more about stereo types of a tribe than knows something that the tribe has. Whereas in the context of multicultural education discourse, understanding the meaning behind the cultural reality of an ethnic group is essential. Therefore the implementation of multicultural education as a conscious effort to develop personalities inside and outside of school for students and students needs to be strengthened with a rule from the stakeholders. Multicultural education in an educational institution is said to be successful when formed in students and students' attitudes to life are tolerant, non-hostile and non-conflicting caused by differences in culture, ethnicity, language, customs, territories, and others (Slamet, 2017). According to Stephen Hill (in Mahfud, 2011) Representative Director of the UN Agency for Education, Science and Culture, UNESCO for the regions of Indonesia, Malaysia, the Philippines and Timor Leste; multicultural education can be 
said to be successful if the process involves all elements of society. Concretely, multicultural education does not only involve teachers/lecturers or the government but all elements of society. This needs to be done because the Indonesian nation-state has multidimensional aspects of life that are covered in multicultural education. The expected change in the context of multicultural education does not lie in the justification of numbers or statistics and the cognitive orientation of an sich as is commonly the assessment of success in the implementation of education in this country. But more than that, in the creation of comfortable conditions, peace, tolerance in people's lives, and conflicts do not always arise due to cultural differences and racial intolerance. Some people even say that the results of multicultural education cannot be determined by a certain time standard (Supardan, 2005). Therefore, in the context of Indonesia's education world, it is time to pay great attention to multicultural education, thereby indirectly providing solutions to a number of social problems facing the nation-state of Indonesia in the future.

Regarding multiculturalism in the study of history, multicultural values have actually been owned by the ancestors of the Indonesian people, even those multicultural values long before the Indonesian people recognized writings known as pre-literacy. Mutual cooperation, social system, belief system, culture, and so on are real examples of multicultural values that have been owned by the ancestors (Slamet, 2016). The multicultural values become the basis for the development and periodization or subsequent history so that the previous periodization becomes the basis and inseparable from the subsequent multicultural values, and so on, so that the multicultural values cannot stand alone. Past multicultural values are still used and continue to live in the next period.

While historians agree that the period of time in the proclamation of Indonesian National History is known to have 4 (four) periods, namely: 1) prehistoric / pre-literate Indonesia; 2) ancient Indonesian / HinduBuddhist history; 3) the history of Indonesian intermediate/entry of Islam and Western nations; 4) the history of new Indonesia which continues into the history of modern Indonesia or contemporary history that has taken place until now (Gazalba, 1981). It was further stated that based on the history of history and findings related to multicultural values according to their period, this exposure focused on Indonesian prehistoric / praxara so that the objectives of this study describe: 1) the social system; 2) belief system; 3) science and technology; 4) artistry; 5) agriculture; and 6) shipping.

\section{RESEARCH METHODS}

This type of research used as descriptive research material, while the form of research 
used the content analysis model (content analysis) then in the implementation of the investigation of the content analysis procedure (Creswell, 2009). This study used the subject of an event or events that exist in the community on certain content. Developed by the author in developing data by 2 (two) steps or procedures, namely: 1) procurement of data which includes (1) careful and repeated reading unit analysis, (2) recording and/or recording of related data consisting of symbolic data that was not structured; and (3) data validation, namely the use of semantic validation patterns to measure the level of sensitivity of symbolic meaning related to context; and 2) the process of inference and analysis as one of the content analysis procedures. This inference was interesting to draw abstract conclusions, then did the presentation and discussion of data obtained according to the field in order to provide clarity for those obtained.

\section{DISCUSSION}

Culture and society are inseparable unity. Society can survive because it produces culture, otherwise, culture exists because it is produced by the community. Through culture, all the features of community life can be known, then the results of material culture in the prehistoric/prehistoric times can be studied and studied from the patterns of community life related to multicultural values so that the results and at the same time the discussion can be presented in sequence as follows

\section{Community Social System}

During the hunting and gathering of food, the community lived in small numbers, but the relationship between the groups was already tight because members had to be together $(=$ mutual cooperation? $)$ Facing severe natural conditions, while the social system that emerged at that time still very simple. During farming, the lives of people who have settled increasingly experience development and this is what drives the community to shape the regularity of life. Rules of life can be implemented well, because of a leader who is chosen based on deliberation. Furthermore, the social system continues to develop, especially at the time of legislation, because at that time community life is more complex which is divided into groups according to their fields of expertise. Each group has its own rules of the agreement, in addition to the existence of general rules that guarantee harmonious relations of each group. General rules are made based on mutual agreement/deliberation in democratic life. Thus the social system in the pre-literacy period in Indonesia has been based on consultation and mutual cooperation

The explanation above illustrates that in the days of the ancestors, noble values in the form of cooperation and mutual cooperation have been carried out. This illustrates and provides an understanding that if welfare is to 
be obtained together, mutual cooperation involving relatively large members of the community is needed so that a leader is needed, while the method of determining a leader is chosen through the word consensus. Those are multicultural values as the noble values of the Indonesian nation-state that our ancestors actually owned and carried out. If it is related to the present condition, the multicultural values are almost faded and increasingly extinct, as evidenced by frequent student brawls, even as the nation-state spectrum is stiffened by inter-ethnic groups and ethnic groups who do not see as an Indonesian nation-state. According to the opinion of the writer, in this position, multicultural education needs to be given to an educational institution in order to provide fundamental awareness to students and students about how to respect differences of opinion, the need for cooperation, and mutual assistance especially for people who are framed in the Unitary Republic of Indonesia (NKRI) ) plural.

\section{Belief System}

The belief system (= religion) of prehistoric/prehistoric communities is estimated to have begun to grow during the hunting and gathering of advanced food or also called the period of settling and farming that occurred during the Mesolithic era. Other evidence that helped strengthen the pattern of belief in that era was found in a boat painting in Nekara depicting vehicles that deliver ancestral spirits to the afterlife. This means that at that time had believed the existence of the spirit. Trust in the spirit continues to develop in the prehistoric/prehistoric times, it can be seen from the complexity of the forms of ceremonies, burials, and offerings. This belief in the spirit is known as animism (the existence of spiritual forces outside the human soul), in addition, there is also a belief in dynamism (trust in certain objects that are considered to have supernatural powers). For example, axe made of chalcedon stone (beautiful stone) is considered to have strength, in addition to dagger, spear, talisman, and examples of other objects. The totemism is a belief on the basis of the belief that certain animals are ancestors (exceeding the power possessed by humans) of a particular society. Animals that are considered as ancestors between members of the community are different from one another. Usually, animals that are considered incarnations of ancestors should not be hunted and eaten, except for certain ceremonial purposes. This means that the belief system of prehistoric / pre-literacy society is animism, dynamism and totemism.

The pre-literate belief system reflects the belief in the existence of spirits, objects and animals that have great/magical powers. If it is related to current conditions, the Indonesian nation-state has agreed to 6 (six) religions (Islam, Kristen Katholik, Kristen Protestan, Hindu, Budha, dan Khonghucu). If the members of the community realize that all 
religions are true and adherents are approved by the Law, then there is no need for bombings which are accused of terrorism and tribal conflict caused by SARA issues. According to the opinion of the author, in this condition, multicultural values need to be given to education in order to provide awareness to students and students about ways to save religion and its adherents because in principle all religions are true.

\section{Science and technology}

Since the Neolithic era the ancestors of the people have known high knowledge, it can be known from the use of monsoons as a driving force in trading and shipping activities as well as astronomy or astrology as a direction for sailing or as a time guide in agriculture. In addition to the development of science, technology is also known by the prehistoric community, especially in the era of perundagian namely metal casting technology, so that at this time people have been able to produce life tools made of metal, such as funnel axes, nekara, moko, and various goods jewellery. Based on the explanation above, according to the opinion of the writer in this condition, urgent multicultural values are given to educational institutions in order to provide understanding to students and university students that mastery of technology is important but do not forget to uphold the nation's noble values, as well as respecting differences, cooperation, deliberation, consensus, as a feature of the nation that has been owned since prehistoric / pre-literacy times.

Art

Art (= culture $)$ has been known by prehistoric communities since the time of Mesolithikum as evidenced by the paintings on cave walls. Furthermore, the arts experienced rapid development in the Neolithic era, because during the farming period there was free time from planting to harvest, which was used by the community to channel their artistic souls. Specifically, sources that state about art produced in prehistoric/prehistoric times have not provided the details as in present times, but at least the tools produced for use in hunting and gathering food such as spear shape models, wood splitting forms, and life equipment day-to-day has shown that the ancestors already had quite a taste and aspiration of beauty related to art, it developed in the next period and period, namely in the era of Ancient Indonesia and Middle Indonesia which produced batik, gamelan, and wayang.

\section{Agriculture}

The agricultural system (= economy) known to prehistoric / pre-literacy communities was originally cultivation that only relied on topsoil, so the form of agriculture was to move from place to place. Furthermore, the community began to develop the rice field system, so that it was no longer dependent on topsoil, and tried to overcome soil fertility through processing, irrigation, and fertilizing. The rice field system was known by 
the prehistoric / pre-literacy community during the Neolithic period because at that time people's lives were settled and organized. During the revision of the paddy system, it developed because of specialization or division of tasks based on expertise, so the prehistoric community was increasingly adept at processing rice. Based on the explanation above, it can be stated that the agricultural system in Indonesia has been owned by the ancestors with the application of quite high technology, even to this day the traditional land management done using a hoe has evolved and changed using a tractor.

\section{Sailing}

Sailing includes trade, economy, culture, science and technology can be studied from the migration of other nations to Indonesia. The movement of nations from mainland Asia to Indonesia proves that since century BC, the ancestors of the Indonesian people had the ability to sail. The ability to sail continues to develop because Indonesia's geographical conditions consist of islands so that to arrive at other islands a boat must be used. The type of boat used is a boat. The existence of the making and ownership of a simple boat, but was able to sail the ocean in the prehistoric era. It should be proud of the great ability to sail our ancestors to be the basic capital of the ability to trade so that at the beginning of the century the Indonesian people took part in the path of international trade. This condition has developed until now, so it is not surprising that the Indonesian nation-state involved and coloured economic activities in the global world trade.

\section{CONCLUSION}

Based on the description that has been stated above it can be stated that one of the great problems of this nation is the awareness of the identity of a nation-state. This is due to 2 (two) waves of social change, namely globalization and democracy. Globalization is the main problem not only for people in the fields of trade, politics, economics but also in the field of philosophy and of course also in the world of education. Many experts have discussed globalization, positive and negative values, and there are even very sceptical about the effects of globalization in human life. However, the reality of human life in the $21 \mathrm{st}$ century shows the occurrence of social transformation that has never been experienced by mankind to escape from the current that can eliminate or marginalize the identity of a society, ethnicity, language, belief (religion), and culture as one's identity in the nation-state. At the global level, besides the existence of world powers such as in politics and trade, there is also a power that wants people to have an awareness of identity as well as the Indonesian nation-state.

Indonesia is one of the largest multicultural countries in the world. The truth of that statement can be seen from the sociocultural and geographical conditions that are 
so diverse and broad. At present, the number of islands in the territory of the Republic of Indonesia is $\pm 13,000$ large and small islands, with a population of more than 200 million people consisting of 300 tribes using \pm 200 different languages. Besides that, there are also various religions and beliefs, such as : Islam, Kristen Katolik, Kristen Protestan, Hindu, Budha, and various beliefs. That diversity is recognized or will not have an impact on various problems that must be faced by the nation-state. Corruption, collusion, nepotism, political feuds, poverty, violence, separatism, environmental destruction and loss of humanity to always respect the rights of others are manifest forms of the multiculturalism problem.

The advice given related to the events and conditions above is, multicultural education is not only seen as a discourse but needs to be immediately implemented by the government. This is seen as very urgent because multicultural education is intended to respond to the phenomena of ethnic, social and cultural conflict, and the region that often arises in a pluralistic society. The multicultural face in this country up to now is like a fire in the husk which could one day bring up a heated political, religious, socio-cultural temperature, which allows the conflict to re-emerge. Therefore, it becomes a necessity for all members of the community to think of solutions, including those responsible, are the education community (read: government).
Education should have a role in resolving conflicts that occur in the community, that conflict is not a good thing to be cultivated. Education should also be able to provide a smart offer, for example by designing material, methods, and curricula that are able to realize the importance of mutual tolerance to respect differences: ethnicity, religion, race, ethnicity, culture, language, and region. The multicultural Indonesian nationstate should place education as a medium for social, cultural and multicultural transformation, so it is natural to develop a new paradigm in the world of education, namely a multicultural education paradigm that leads to the student's creation to understand, respect differences in culture, ethnicity, religion, taste, ethnicity, language, region, and others that exist in society and in the frame of the Unitary Republic of Indonesia.

\section{REFERENCES}

[1] Creswell, W. John. (2009). Research Design: Qualitative, Quantitative, and Mixed Methods Approaches. Third Edition. California: Thousand Oaks.

[2] Gazalba, Sidi.(1981). Pengantar Sejarah sebagai Ilmu. Jakarta: Bhatara Karya Aksara.

[3] Mahfud, Choirul.(2011). Pendidikan Multikultural. Yogyakarta: Pustaka Pelajar.

[4] Naim, Ngainun dan Sauqi, Achmad.(2011). Pendidikan Multikultural: Konsep dan Aplikasi. Yogyakarta: Ar-Ruzz Media.

[5] Parekh, Bhikhu.(2012). Rethinking Multiculturalism: Keberagaman Budaya dan Teori Politik. Yogyakarta: Kanisius. 
[6] Slamet,etc. (2017). The Implementation of Multicultural Values in The Education Institution. Journal of Education Development. Vol: 5, No. I, 2017.

[7] Slamet. (2016). Penerapan Nilai-nilai Multikultural dalam Institusi Pendidikan. Majalah Pawiyatan,Vol: XXIII, No. I, Mei 2016.

[8] Slamet. (2017).Pengembangan Model Manajemen Pelatihan Penyusunan Bahan Ajar Berbasis Nilai-nilai Multikultural bagi Guru Sejarah SMA. Disertasi Tidak Dipublikasikan. Semarang: Universitas Negeri.

[9] Supardan, Dadang.(2005). Pembelajaran Sejarah Berbasis Pendekatan Multikultural dan Perspektif Sejarah Lokal, Nasional, dan Global dalam Integrasi Bangsa. Disertasi. Bandung: Universitas Pendidikan Indonesia. Tidak dipublikasikan.

[10] Supriyoko (2011). Membangun Indonesia: Menuju Masyarakat Multikultural dalam Persepktif Pendidikan. Makalah.Yogyakarta: Universitas Sarjanawiyata Tamansiswa. 